\title{
発電所における高張力鋼の溶接*
}

$$
\text { イ・クルアニン** カ・ベ・リュバフスキー** }
$$

\section{Welding of High Strength Steels in Power Engineering*}

\author{
by I.R. Kryanin** and K.V. Ljubavskij**
}

近年発電可の大容量化は, 発電所の機器類を製造する にあたって発電機の大きさや重量を減らす目的で, 高張 力鋼の使用を要求している.

下に述べるいくつかのデーターは，大容量の水力発電 所用の鉱造および溶接されたホィールの製作に用いられ た OCr $12 \mathrm{NiCuL}(\mathrm{OCr} 12 \mathrm{NiCu})^{* * * *} ク$ ム鋼の溶接之 火力発電所用の大容量ボイラーのドラムに用いられたマ ンガン・ニッケル・モリブデン鋼, $16 \mathrm{MnNiMo}$ の溶接 に関するあのである。

\section{OCr 12 NiCuL 鋼}

$\mathrm{OCr} 12 \mathrm{NiCuL}$ 鋼は，水力発電機用のホィールとター ビンブレードとを溶接組立てするために開発されてき た. ての鋼は, 以前, 水力発電機のタービンに用いられ てきたクロムステンレス鋼に比べて炭素量を $0.1 \%$ 以下 に下げられている. 鋼中の炭素含量の低下は，材料の割

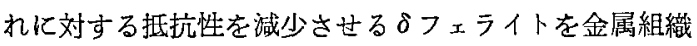
中にかなり生じさせるので, ての鋼はオーステナイト生 成元素であるニッケルとか銅を合金されている，との場 合，銅は金属の分散強化をし，かつ割れに対する抵抗性 を增大させる。この OCr $12 \mathrm{NiCuL}$ 鋼は次のような化学 組成を有する; 炭素 $0.1 \%$ 以下, クロム $13 \%$, ニッケル $1.0 \sim 1.5 \%$ ，銅0.9〜1.2\%である ${ }^{132) 33 .}$

ての鏑で、ニッケルを一部または全部マンガン $(0.5$ 〜 3.5\%)，モリブデン $(0.5 \sim 2.3 \%)$ ，タングステン (1 $\%$ 以下), バナジウム $(0.5 \sim 0.6 \%)$ やボロン $(0.8 \%$ 以 下）で置き換えた種々の組成の鋼の研究は, $\mathrm{OCr} 12 \mathrm{CuL}$ 鋼の基本組成に比較して優れていないてとを明らかにし ている.

OCr $12 \mathrm{NiCuL}$ 鋼の変態点および熱処理条件に関する 詳細な研究は, 大型の鋳鋼部品の場合, 次の熱処理条件.

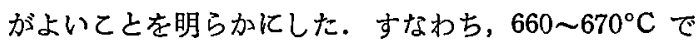

* 原稿受付 昭和44年11月24日 (IIW 京都火会 Public Session $\sigma$ "Use of high strength materials in welded constructions" の翻訳

** Kryanin 数授 ソ連溶接委員会委員 Ljubavskij 教授 中央重機械技郝研究所溶接部舆

*** 添字 “L”は鋳銀を，添字のないしのは鋸造鋼を意味する。
焼戻し後炉中冷却, $950^{\circ} \mathrm{C}$ で戻ならし，静かな大気中で 冷却, $660 \sim 670^{\circ} \mathrm{C}$ で焼戻し後炉中泠却.

との熱処理を完了すれば， OCr $12 \mathrm{NiCuL}$ 鋳鋼の顕微

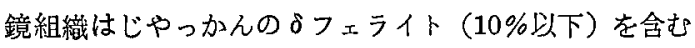
焼戾しマルテンサイト之なる。鈠造した場合の顕微鏡組 織は鋳造状態よりさらに均質なものとなる．乙の鋳鋼扔 上び鍜造銅の機械的性質を Table 1 および Fig. 1 に示 ఫ.

Table 1 熱処理後の OCr 12 OiCuL および $\mathrm{OCr} 12 \mathrm{NiCu}$ 鋼の機械的性質

(平均值)

\begin{tabular}{|c|c|c|c|c|c|}
\hline 鋼 & $\begin{array}{l}\text { 降 伏 点 } \\
\mathrm{kg} / \mathrm{mm}^{2}\end{array}$ & $\begin{array}{l}\text { 引張り強さ } \\
\mathrm{kg} / \mathrm{mm} 2\end{array}$ & 伸び & $\begin{array}{l}\text { 蟀り } \\
\%\end{array}$ & $\begin{array}{l}\text { 衝䡶 值 } \\
\mathrm{kg} / \mathrm{m} / \mathrm{cm}^{2}\end{array}$ \\
\hline$\underset{\text { (赫) }}{\mathrm{OCr} 12} \mathrm{NiCuL}$ & 59 & 70 & 19 & 62 & 10.0 \\
\hline 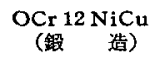 & 65 & 80 & 19 & 64 & 6.0 \\
\hline
\end{tabular}

(a)

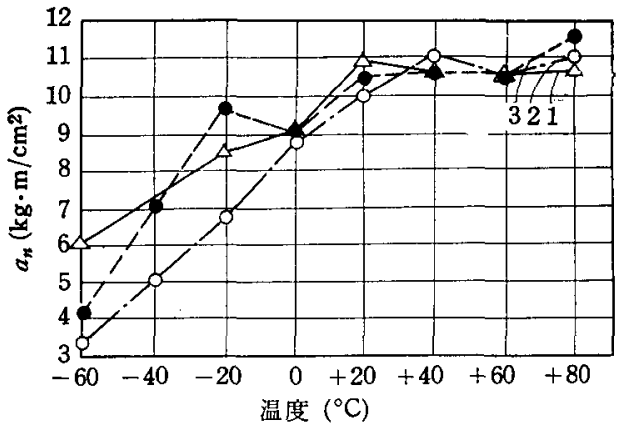

(b)

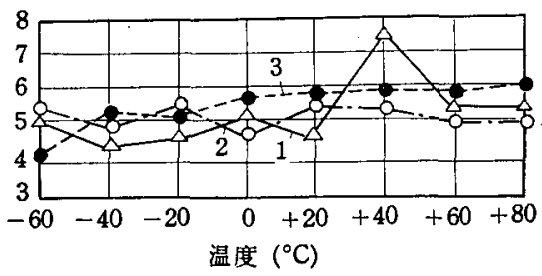

Fig. 1 衝 撃 值

a) $\mathrm{OCr} 12 \mathrm{NiCuL}$ 鋳鋼

b) $\mathrm{OCr} 12 \mathrm{NiCu}$ 鋠造鋼 焼ならし温度 1） $950^{\circ} \mathrm{C}$

2) $1050^{\circ} \mathrm{C}$

3) $1150^{\circ} \mathrm{C}$ 


\section{OCr $12 \mathrm{NiCuL}$ 鋼の溶接}

OCr $12 \mathrm{NiCuL}$ 鋼の溶接は，実際上母材之同程度の炭 素, クロムおよびニッケルを含む TSL-41 被覆搈接棒 により行われる （400 mm 以下）の溶接の場合には $200^{\circ} \mathrm{C}$ 以下の予熱を 行なう.この鋼種の溶接に対して,オーステナイト系被 覆溶接棒, TSL-25（25-13型）を用いれば, 予熱は特 別な場合以外しなくてすよい，溶接金属の機械的性質を Table 2 亿示方.

$\mathrm{OCr} 12 \mathrm{NiCuL}$ 鋼のエレクトロスラグ溶接および $\mathrm{OCr}$ $12 \mathrm{NiCuL}$ 鋼之 $20 \mathrm{MnSiL}$ 鋼の異材継手の研究開発を行 っだ78). OCr $12 \mathrm{NiCuL}$ 鋼のエレクトロスラグ溶接は, SV-10Cr 13 ワイヤ $(0.08 \sim 0.15 \% \mathrm{C}, 12 \sim 14 \% \mathrm{Cr})$ と AN-8 または AN-348 フラックスの組合せにより，予熱 温度 $200^{\circ} \mathrm{C}$ 以下で行なった ${ }^{910)}$. 乙の場合の溶接継手の 機械的性質は, Table 2 亿示すでとく，焼戻し状態およ び焼ならし後焼戻しの状態で極めて満足しうるものであ った.

異種鋼材でホィールを組立てる必要性から，異なる合 金鋼継手の溶接条件を調べた ${ }^{8}$ )。(上部りムが $20 \mathrm{MnSiL}$ 鋼で,タービンブレードと下部リムは $\mathrm{OCr} 12 \mathrm{NiCuL}$ 鋼).

この溶接は溶着金属の合金組成を比較的低くするよう な特別な施行法により行なったすすなわち，両開先面に アームコ鉄を肉盛し，SV-04 NiMっ ワイヤを使用して溶 接した.これによって母材端面の溶け込み樑さが溶接金 属の性兵におよばす影響をいちじるしく小さくするとよ ができた（Fig. 2).

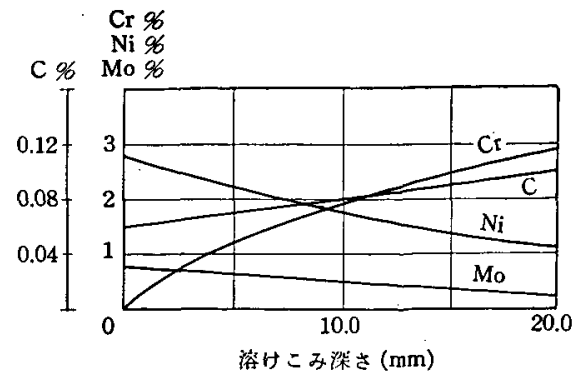

(a)

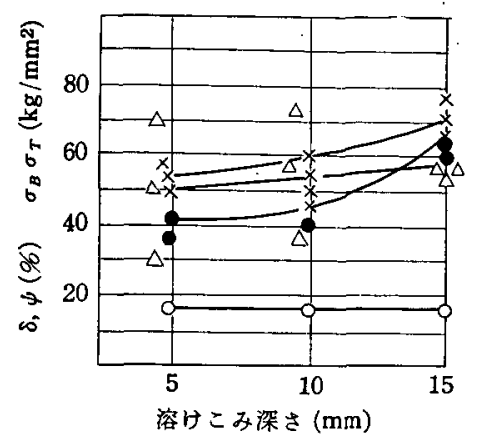

(b)

Fig. 2 エレクトロスラグ溶接（アームコ鉄によ り開先面の肉盛溶接)の溶けこみ深さの

a ) 溶着金属の化学組成

b ) 機械的性質

に枋よばす影響

\section{冷間割れ試験}

IMET-DB 法行によオーステナイト変態の動力学的 研究は次のことを明らか䎲した，すなわち OCr $12 \mathrm{MiCu}$ 鋼はオーステナイトの高い安定性を有しているので,

Table 2 OCr $12 \mathrm{NiCuL}$ 鋼の溶着金属の諸性質 (TSL-41, TSL-2.5

溶接棒に上る手溶接とエレクトロスラグ溶接)(平均値)

\begin{tabular}{|c|c|c|c|c|c|c|c|c|c|c|c|c|}
\hline \multirow{2}{*}{ 溶 } & \multicolumn{6}{|c|}{ 溶着金属の化学組成 \% } & \multirow{2}{*}{$\begin{array}{l}\text { 溶接後の } \\
\text { 熱処 理 }\end{array}$} & \multicolumn{2}{|c|}{ 機 } & \multicolumn{2}{|l|}{ 的 } & 筫 \\
\hline & C & $\mathrm{Si}$ & $\mathbf{M n}$ & $\mathrm{Cr}$ & $\mathrm{Ni}$ & $\mathrm{Cu}$ & & $\begin{array}{l}\text { 降 伏 点 } \\
\mathrm{kg} / \mathrm{mm}^{2}\end{array}$ & $\begin{array}{l}\text { 桀張り䖯さ } \\
\mathbf{k g} / \mathbf{m m}^{2}\end{array}$ & $\begin{array}{c}\text { 伸び } \\
\%\end{array}$ & \begin{tabular}{|} 
䌏り \\
$\%$
\end{tabular} & 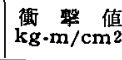 \\
\hline 手溶接，TSL-41 溶接棒 & 0.06 & 0.12 & 0.40 & 13.0 & 1.4 & 一 & $670^{\circ} \mathrm{C}$ 焼底 ᄂ & 64.0 & 75.0 & 16.0 & 55.0 & 9.0 \\
\hline 手溶接, TSL-25 溶接桠 & 0.10 & 0.60 & 1.80 & 22.0 & 10.0 & - & 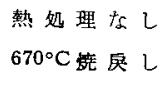 & $\begin{array}{l}55.0 \\
35.2\end{array}$ & $\begin{array}{l}72.0 \\
58.0\end{array}$ & $\begin{array}{l}30.0 \\
36.4\end{array}$ & $\begin{array}{l}43.0 \\
43.0\end{array}$ & $\begin{array}{l}8.5 \\
8.6\end{array}$ \\
\hline ェレクトロスラグ溶接 & 0.12 & 0.32 & 0.58 & 12.1 & 0.91 & 0.66 & 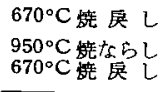 & $\begin{array}{l}56 \\
59\end{array}$ & $\begin{array}{l}66 \\
70\end{array}$ & $\begin{array}{l}14.0 \\
16.0\end{array}$ & $\begin{array}{l}54 \\
66\end{array}$ & $\begin{array}{l}7.5 \\
7.5\end{array}$ \\
\hline 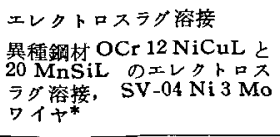 & $\begin{array}{l}0.09 \\
0.09\end{array}$ & $\begin{array}{l}0.24 \\
0.48\end{array}$ & $\begin{array}{l}0.58 \\
0.90\end{array}$ & $\begin{array}{l}1.8 \\
3.80\end{array}$ & 1.95 & $\begin{array}{l}0.40^{* *} \\
0.25^{* *}\end{array}$ & 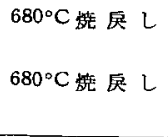 & $\begin{array}{r}41.5 \\
48.5 \\
.\end{array}$ & 63.0 & $\begin{array}{l}20.0 \\
19.0\end{array}$ & $\begin{array}{l}69.0 \\
64.0\end{array}$ & 11.0 \\
\hline
\end{tabular}


冷却速度が $1.5^{\circ} \mathrm{C} / \mathrm{sec}$. またはそれ以上の速度でのみマ ルテンサイト変態が生じ，とのマルテジサイト変態は $400^{\circ} \mathrm{C} \cdot$ で始まり $220^{\circ} \mathrm{C}$ ，または泠却速度が速い場合てれ より少し低目の温度で終了する。

OCr $12 \mathrm{NiCuL}$ 銅のヴィッカース硬さは，冷却速度を $1.5^{\circ} \mathrm{C} / \mathrm{sec}$ 方ら $83^{\circ} \mathrm{C} / \mathrm{sec}$. まで変えた場合， 330 から 375 に変化するのみで，冷却速度に上る硬度上昇はほ上 んど無視できる。

溶接入熱が 862 から $5,760 \mathrm{Cal} / \mathrm{cm}$ まで変化しても (この場合の $550^{\circ} \mathrm{C}$ から $500^{\circ} \mathrm{C}$ までの冷却速度はおの おの $117^{\circ} \mathrm{C} / \mathrm{sec}$ および $17^{\circ} \mathrm{C} / \mathrm{sec}$ ), 熱影響部でヴィッ カース硬さは 377 加ら 348 の範圈で, 街撃值は 5.0 から $7.5 \mathrm{~kg} \cdot \mathrm{m} / \mathrm{cm}^{2}$ の箱囲内にある，乙の場合の熱影響部の 組織はマルテンサイトと少量の $o$ フェイトと1.0〜1.5 \%の残留オーステナイトである.

冷間割れ（遅れ破壤）試験は IMET-4 試験法4)，CTS

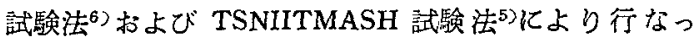
た. Fig. 3 に示す IMET -4 試験法の試片は, 中央のく

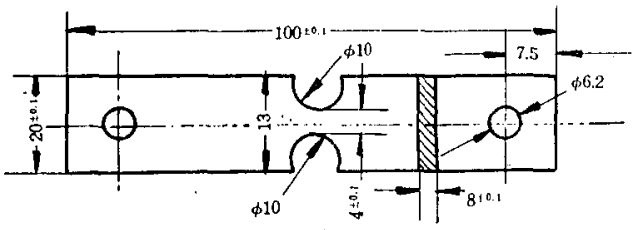

Fig. 3 遅れ破壞試験用の IMET-4 試牌4)

びれた部分に多層溶接が終了した場合之同様の熱サイク ルを与えられる。そして，冷却曲線の必要な温度笔团で 試片に設定された灾力を負荷する。まず陚片は $550^{\circ} \mathrm{C}$ 加 $400^{\circ} \mathrm{C}$ で, $30 \mathrm{~kg} / \mathrm{mm}^{2}$ 以下の応力を加， 250 。 $100^{\circ} \mathrm{C}$ の冷却過程でさらに応力を高くする.てうして，

試片はさらに室温で25日間応力を負荷したままにしてお く. $120 \mathrm{~kg} / \mathrm{mm}^{2}$ 以下の応力では遅れ破墑は観祭されな 汃た：さらに応力を高くする亡，目荷過程で破燷が生 ずるが，とれはすはや荤れ破塤ではない。

CTS 試験法と TSNIITMASH 試験法による試験は，

Fig. 4 および Fig. 5 亿示すおのおのの試片をそれぞれ オーステナイト系（TSL-25)，マルテンサイト系 (TSL -41)およびパーライト系 (TSU-1) 被復溶接棒で溶接し て行なった.

CTS 試験においては，板厚を種々に変えた Fig. 4 の 多くの試片を各溶接棒で溶接した．Table·3 のデータ-

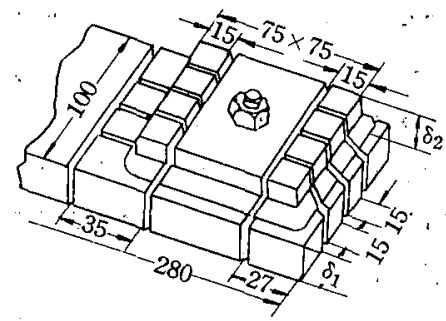

Fig. 4 CTS 試験片。試験片の片側半分のみを示す

Table 3 溶接継手の CTS 試験の結果 ( OCr $12 \mathrm{NiCuL}$ 鋼)

\begin{tabular}{|c|c|c|c|c|}
\hline 䐍 & 接 & 棒 & 剽れの発生㑉所 & $\begin{array}{l}500^{\circ} \mathrm{C} \text { に护方熱影梆部 } \\
\text { の臨界冷地速度 }{ }^{\circ} \mathrm{C} / \mathrm{sec}\end{array}$ \\
\hline \multicolumn{3}{|c|}{$\begin{array}{l}\text { TSL-25 } \\
(\mathrm{Cr} 25 \mathrm{Ni} 13)\end{array}$} & な $\iota$ & . 34 \\
\hline \multicolumn{2}{|c|}{$\begin{array}{l}\text { TSU-1 } \\
\text { (低宸素鋮) }\end{array}$} & & 熱 影 製 㔊 & $14-17$ \\
\hline \multicolumn{3}{|c|}{$\underset{(\mathrm{OC} r \cdot 12 \mathrm{Ni})}{\operatorname{TSL}-41}$} & 溶 著 金 程 & $21-28$ \\
\hline \multicolumn{3}{|c|}{ 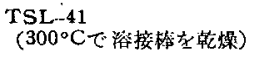 } & 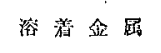 & 28 \\
\hline
\end{tabular}
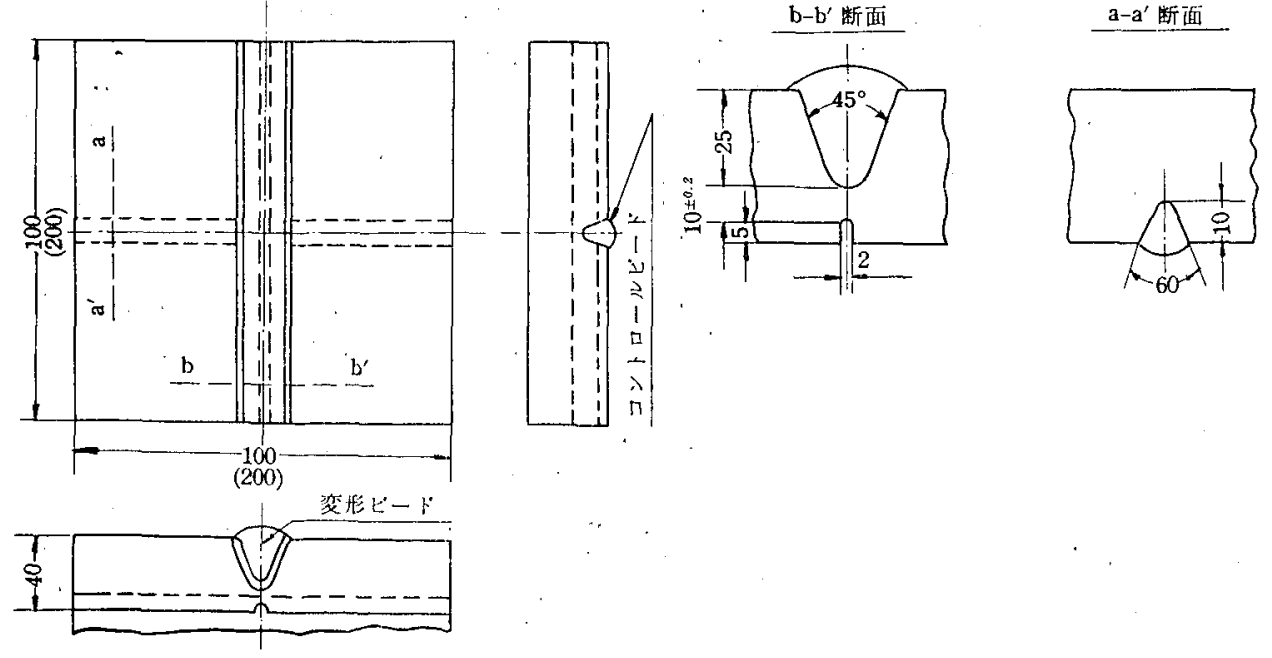

Fig. 5 TSNIITMASH 法による試験片 ${ }^{5}$ ) 
からオーステナイト系被覆溶接棒（TSL-25）による 溶接継手は最す高い耐割れ性を有することがわかる。こ の点に関して，TSL-41 被劕溶接棒による溶接継手むま たよい結果を示した。

TSNIITMASH 法による試験は，2本のV溝を多層溶 着するもので，最初に溶着するコントロールビードに は，応力集中のための切欠きをつけておく（Fig. 5). まずコントロールビードは 4 層で容着し，切欠きをミー リングでつける. そして, 板の反対側に変形ビードを置 く.

コントロールビードの切欠きに生ずる割れは，変形ビ ードの層数を減らせば防げるし，また溶接の際の熱的な 条件を変えれば防げる。したがってての試験法では，二 つのグループ（ａｂ）吕規定されている.

グループ“a”の試験では, 試片の大きさは $100 \times 100$ $\times 40 \mathrm{~mm}$ である。溶接中試片は， $18^{\circ} \mathrm{C} \pm 1^{\circ} \mathrm{C}$ の水シ ェットにより反対側加ら急冷される. 変形ビードの層数 を1〜12まで変えて一系列の試片を溶接し，割れを生じ ない最大の層数を求める。溶接継手の割れ抵抗は 1 (最 屯悪い) から 5 (最す良い) の記号で評価される。

グループ “b”の試験では, 試片の变形ビードの層数 は一定とする゙、種々の熱的な条件で一系斺の試片の溶接 を行ない，溶接継手で割れを生じない最低の予熱温度を 求める.

これらの試験で, 割れは概してV清の角近傍の最大の 応力集中箇所で生ずる.しかしながら，割れはビード全 長にわたり生ずるとともあり，あるいは“相” (pailing) の形で熱影響部のいたる所住ずるととるある.

TSNIITMASH 法による試験結果を Table 4 および Table 5 亿示す.こ扎らの結果は, OCr $12 \mathrm{NiCuL}$ 鋼を

Table 4 TSNIITMASH “a” 法による OCr $12 \mathrm{NiCuL}$ 鍋の溶接継手の試験結果の比較

\begin{tabular}{|c|c|c|c|c|c|c|}
\hline \multirow{2}{*}{ 浴接譛 } & \multicolumn{5}{|c|}{ 变形ビードの層数と制れ発生状況 } & \multirow{2}{*}{ 判定 } \\
\hline & 1 & 3 & 6 & 9 & 12 & \\
\hline TSL-25 & - & - & ts 2 & なし & 热影被 & 4 \\
\hline TSL-41 & - & なし & 涳葆金属 & 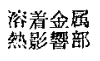 & 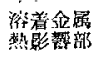 & 2 \\
\hline $\begin{array}{l}\text { TSL-41 } \\
300^{\circ} \mathrm{C} \text {. } \\
\text { 䗆 }\end{array}$ & - & なL & ts $\mathrm{L}$. & 溶着金咶 & 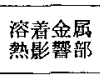 & 3 \\
\hline
\end{tabular}

TSL-41 被覆溶接棒により予熱温度 $200^{\circ} \mathrm{C}$ 以下で溶接 すれば，割れのない無欠陥の溶接ができるととを証明し ている. 予熱之同時に溶接棒被覆剂の水分に注意を払う ことは，溶着金属の水素吸収を最小限にするのに必要な ことである.
Table 5 TSNIITMASH "b" 法による OCr $12 \mathrm{NiCuL}$ 狳の溶接継手の試験結果の比較

\begin{tabular}{|c|c|c|}
\hline \multirow{2}{*}{ 溶接の熱的条件 } & \multicolumn{2}{|c|}{ 溶接棒による搈接部の割れ } \\
\hline & TSL-41 & TSL -25 \\
\hline 水 & 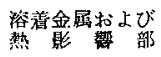 & 热影算 部 \\
\hline 空 & $" \prime$ & $n !$ \\
\hline $100 \sim 150^{\circ} \mathrm{C}$ 予熱 & $" 1$ & $" n$ \\
\hline $200^{\circ} \mathrm{C}$ & 制れ発生せず & 制れ発生せず \\
\hline $250 \sim 300^{\circ} \mathrm{C}$ 予熱 & " & $" \prime$ \\
\hline $400 \sim 450^{\circ} \mathrm{C}$ - & $"$ & $\therefore$ \\
\hline
\end{tabular}

\section{疲れ試験とキャビテーション試験}

OCr $12 \mathrm{NiCuL}$ 鋼の溶接継手の繰返し疲れ試験は，断 面 $50 \times 70 \mathrm{~mm}$ の試片を両振り曲げで行なった。溶接棒 TSL-41 およびエレクトロスラグ溶接による継手の渡れ 強さは母材の $14.5 \mathrm{~kg} / \mathrm{mm}^{2}$ 亿等しいととが示された。 TSL-25，溶接棒による場合には，熱処理がない時の疲れ 強さは $10.5 \mathrm{~kg} / \mathrm{mm}^{2}, 670^{\circ} \mathrm{C}$ の焼戻し後は $12.5 \mathrm{~kg} / \mathrm{mm}^{2}$ である。

キャビテーション試験は，磁力による取付け装置の上 で，規則的な腐食を繰り返して行なった，てのような条 件のキャビテーションでは, 溶接継手は母材に比べ少っ ていないことを認めた (Table 6).

Table 6 溶着金属と母材のキャビテーション試験

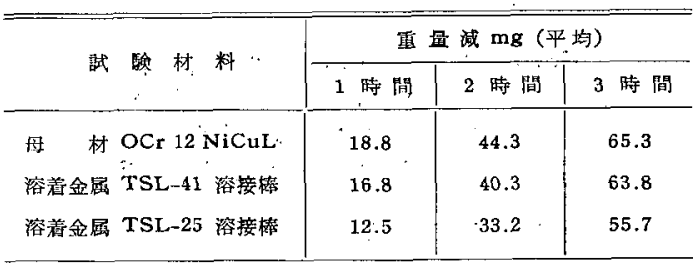

\section{モデル溶接実験と工業用水力発電 機ターピンのホィールの溶接}

溶接棒 TSL-41 による OCr $12 \mathrm{NiCuL}$ 墭の溶接を Fig. 6 亿示す, 板厚 $150 \mathrm{~mm}$ の拘束の大きいモデルで 確めた。 乙の試験体は仮組立てをして，180〜210 ${ }^{\circ} \mathrm{C} の$ 温度に予熱した。溶接は直径 $5 \mathrm{~mm}$ の TSL-41 被覆溶 接棒を用い，180〜210 A で行なった．とうして溶接し た試験体は；アスベスト断熱材中で徐冷した. $670^{\circ} \mathrm{C}$ に 烧戻し後、マクロおよびミクロ検査を詳細に行ない，機 械的性質を調べた.， .

さらに実験的に実物と同一寸法のタービンブレードと 


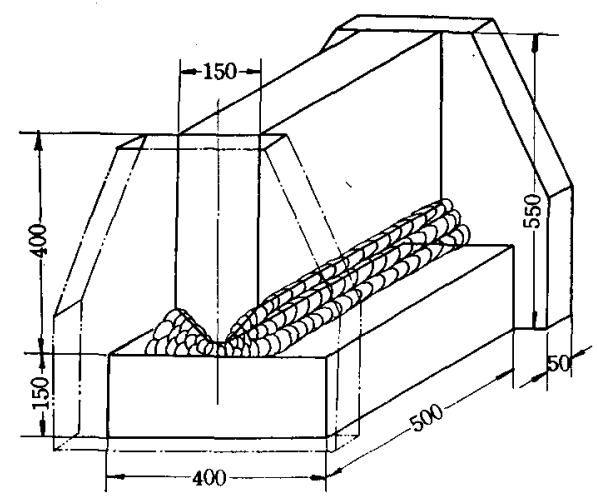

Fig. 6 溶接法の確認試験のための高拘束試験体 破線は前面の壁を示す

板厚 $400 \mathrm{~mm}$ の鍛造材とのエレクトロスラグ溶接を行 ない，溶接継手の久陌検査之諸性質の試験を詳細に行な った (Table 2).

この念入りな手溶接およびエレクトロスラグ溶接の施 行法は水力発電所用軸流タービンのホィールの製造に適 用された ${ }^{15) 16)}$ 。；すなわち，Fig. 7 の Bratsk 水力発 電所向けの 100 トン・ホィールをむつ $255,000 \mathrm{~kW}$ ター ビン怙よび Assuan 水力発電所向けの140トン・ホィー ルをむつ $180,000 \mathrm{~kW}$ タービンはその例である。

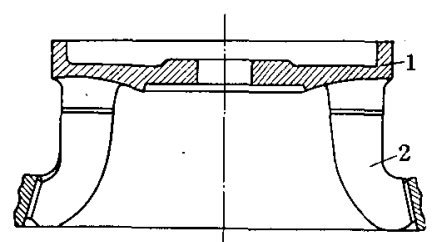

Fig: 7 タービン・ホィールの溶接設計

1) 上部少么 $(20 \mathrm{MnSiL}$ 鋼 $)$

2) タービンブレードおよび下 部リム $(\mathrm{OC} r 12 \mathrm{NiCuL}$ 銅)

\section{MnNiMo 鎡}

高温で操業する高圧容器の重量軽減の必要性は溶接性 のよい高張力鋼の選択の問題を非常に重要にしてきた. 1951 1952 年以来, ソ速では大容量ボイラ一設備のド ラムの製造に 16 MnNiMo 鋼 $(0.13 \sim 0.18 \% \mathrm{C}, 0.17 \sim$ $0.3 \% \mathrm{Si}, 0.8 \sim 1.1 \% \mathrm{Mn}, 1.0 \sim 1.3 \% \mathrm{Ni}, 0.4 \sim 0.55 \%$ Mo）を広範使用してきている(2). 使用板厚とての組 立ての場合の全ての熱サイクルの冷却速度が比較的小さ いことを考慮にいれて，鋼の組成を選択するに当って， 必要な引張り強さは主にフェライト強化の方法で得られ ると考えた.フェライトの諸性質におよ活す各種合金元 素の効果を Fig. 8 亿示す. $16 \mathrm{MnNiMo}$ 鎝は従来鍛造 されたシエルの形で用いられ，底部はサブマージ円周多
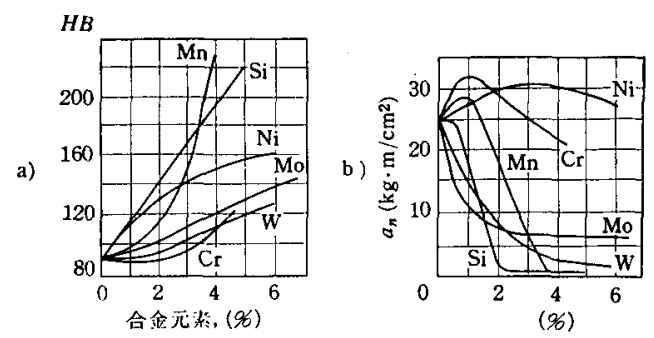

Fig. 8 フェライトの性質におよぼす 各種合金元素の影響13)
a) 硬 さ
b ) 衝撃値

層溶接されていた。近年コスト低減と製造法を簡単にす る目的で，二つの縦割りの玥をエレクトロスラグ溶接し ている.

現在では，板厚 $200 \mathrm{~mm}$ 以上の $16 \mathrm{MnNiMo}$ 敛板が 作られている。

$16 \mathrm{MnNiMo}$ 鋼は次のように熱処理する； $930^{\circ} \mathrm{C} \pm 10$ ${ }^{\circ} \mathrm{C}$ で焼ならしを始め， $930^{\circ}$ から $500^{\circ} \mathrm{C}$ までは $100 \sim$ $150^{\circ} \mathrm{C} / \mathrm{hr}$ の速度で冷却し, 空冷する. そして $670^{\circ} \mathrm{C} \pm$ $10^{\circ} \mathrm{C}$ に焼戻す。焼ならしの $16 \mathrm{MnNiMo}$ 䤱の組織は分 散したわずかに腐食されやすいソルバイト型の微細なつ ェライトである. との鋼を, $670^{\circ} \mathrm{C} \pm 10^{\circ} \mathrm{C}$ で 5 時間烧 戻すと, 組織は安定化し, 炭化物が疑集して均一に分散 するようになる，16 MnNiMo 鋼板の機械的性質の規格 を Table 7 に示す.

Table $716 \mathrm{MnNiMo}$ 鋼板の機械的性質に対する規格

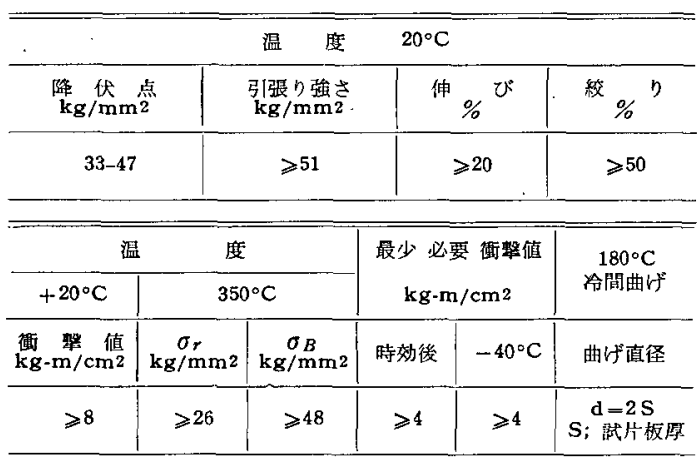

機械試験用の試片は压延方向招よび直角方向の二方向 に板厚の中央の $1 / 3$ の所から切り出されたものである．実 際の機械的性質は一般に要求される規格值以上である.

\section{$16 \mathrm{MnNiMo}$ 鋼の溶接}

次の三つの溶接法が圧力容器の製造および溶接条件に 応じて用いられている，すなわち，a）TSL-21 被覆溶 接棒による手溶接， b ）自動サブマージ多層溶接， c ） エレクトロスラグ溶接. 
最初の溶接法はドラムへ比較的小さな部品（ノズル， スタブ等）を溶接するのに用いられ，またルート溶接や 補修溶接に用いられる。第二のサブマージ溶接法はドラ ムの円周溶接に用いられ，第三のエレクトロスラグ溶接 法はシエルの長手方向の溶接に用いられる.

\section{TSL-21 被覆溶接棒 ${ }^{11}$}

$16 \mathrm{MnNiMo}$ 鋼の手溶接は，乙の目的に合せて作ら れた TSL-21 溶接棒により行なわれることになってい る.とれらの被覆溶接棒は Sv-10 NiMo ワイヤ (GOST 2246-60) で作られる. この TSL 被㠅溶接棒による溶 着金属は次のような平均化学組成を有する； $0.1 \%$ 以 下炭素， $1.2 \%$ ニッケル，0.6\% マンガン扣上び $0.4 \%$

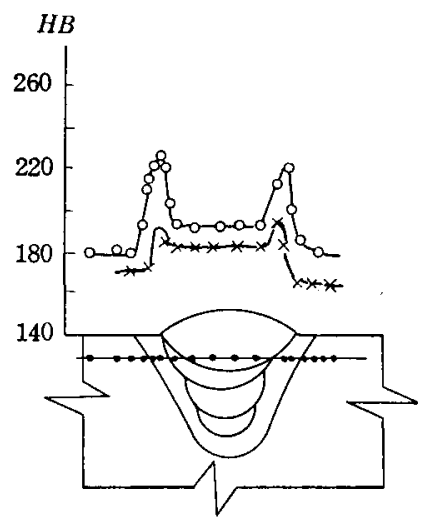

Fig. 9 TSL 溶接棒による四層溶接後の硬さ分布 ${ }^{11}$ a) 溶接のまま b) $670 \pm 10^{\circ} \mathrm{C}$ で焼戾し
モリブデン．溶着金属および溶接継手の機械的性質を Table 8 亿示す.

この鐥は $150 \sim 200^{\circ} \mathrm{C}$ 以下の予熱で溶接する，溶接部 は $670^{\circ} \mathrm{C} \pm 10^{\circ} \mathrm{C}$ で焼戾しをしなければならない，Fig. 9 に四層盛溶接継手の硬さ分布を示す.

\section{サプマージアーク溶接}

この溶接法は主に压力容器の円周溶接を行うのに用い られている. この目的に，従来には FTS-7 フラックス と Sv-10 NiMo ワイヤ，(0.1\%以下宸素, $1.0 \sim 1.5 \%=$ ッケル，0.4〜0.6\%マンガン）の組合せがすすめられて

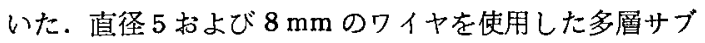
マージアーク溶接条件についての研觉が行われている. 直径 $8 \mathrm{~mm}$ のワイヤによる溶接は溶接継手の欠陥防止之 いう点から好ましい. 圧力容器の突合せ円周溶接の開先 形状はいずれの場合でも同じである (Fig. 10). 直径 $8 \mathrm{~mm}$ のワイヤによる溶接条件を Table 9 に示す.

䡒戻し後の溶着金属および溶接継手の機械的性質を, Table 8 に，さらに烓杘し後時効した場合の機械的性質 を Table 10 と示す. 溶接継手横断面の硬度分布を Fig. 11 と示す.

溶接のままの多層サブマージ溶接金属の組織は, 炭化 物の分散した企状フェライトである．との溶接金属の硬 さは約 $196 \mathrm{HB}$ である。熱影響部はもっと粗いフェライ トーソルバイト組織で硬さは約 $240 \mathrm{HB}$ である（Fig. 11 参炤).

Table 8 板厚 $135 \mathrm{~mm}$ の $16 \mathrm{MnNiMo}$ 鉿板に溶接棒 TSL-21 による手溶接, サブマージアーク溶接

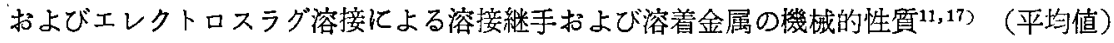

\begin{tabular}{|c|c|c|c|c|c|c|c|c|c|c|}
\hline \multirow{2}{*}{ 溶 } & \multirow{2}{*}{ 熱 妈 理 } & \multirow{2}{*}{\begin{tabular}{|c|} 
武験温度 \\
${ }^{\circ} \mathrm{C}$
\end{tabular}} & \multirow{2}{*}{$\begin{array}{l}\text { 降焦点 } \\
\mathrm{kg} / \mathrm{mm}^{2}\end{array}$} & \multirow{2}{*}{$\left|\begin{array}{l}引 \text { 张り強さ } \\
\mathrm{kg} / \mathrm{mm}^{2}\end{array}\right|$} & \multirow{2}{*}{$\begin{array}{c}\text { 伸 } \\
\%\end{array}$} & \multirow{2}{*}{$\begin{array}{l}\text { 絞 } \\
\%\end{array}$} & \multicolumn{2}{|c|}{ 溶着金属の衝撃值 } & \multicolumn{2}{|c|}{$\mathrm{kg} \cdot \mathrm{m} / \mathrm{cm}^{2}$} \\
\hline & & & & & & & $+20^{\circ} \mathrm{C}$ & $-40^{\circ} \mathrm{C}$ & 時 効 後 & 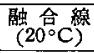 \\
\hline \multirow{2}{*}{$\begin{array}{ll}\text { 溶 } & \text { 接 } \\
\text { 楁接 棒 }\end{array}$} & \multirow{2}{*}{$670 \pm 10^{\circ} \mathrm{C} 1$ 回暁戻し } & 20 & 44 & 58 & 25 & 63 & 17.0 & - & $一$ & 14.0 \\
\hline & & 370 & 42 & 63 & 24 & 57 & 27.0 & - & $\dot{-}$ & 23.0 \\
\hline \multirow{2}{*}{$4 \sim 5 \mathrm{~mm}$} & \multirow{2}{*}{$670 \pm 10^{\circ} \mathrm{C} 2$ 回续戻し } & 20 & 40 & 55 & 26 & 68 & 22.0 & - & - & - \\
\hline & & 370 & 38 & 52 & 26 & 67 & 21.0 & 一 & - & 一 \\
\hline \multirow{4}{*}{$\begin{array}{l}\text { 自 動 浴 接 } \\
\text { FTS-7 フ }-7 \% \text { ス }\end{array}$} & \multirow{2}{*}{$670 \pm 10^{\circ} \mathrm{C} 2$ 回赎房し } & 20 & 36 & 51 & 26 & 69 & 15.0 & - & - & 15 \\
\hline & & 370 & 35 & 50.5 & 22 & 56 & 12.0 & - & - & 12 \\
\hline & \multirow{2}{*}{$670 \pm 10^{\circ} \mathrm{C} 3$ 回読庆 $\mathrm{L}$} & 20 & 32 & 51 & 26 & 65 & 12 & - & - & 14.1 \\
\hline & & 370 & 32 & 51 & 24 & 56 & 11 & - & - & 11.7 \\
\hline \multirow{2}{*}{ 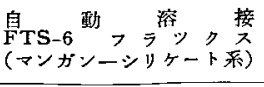 } & \multirow[t]{2}{*}{ 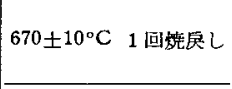 } & & $\begin{array}{l}39 \\
37\end{array}$ & & & 55 & 8.2 & 5.8 & 6.1 & 9.1 \\
\hline & & 370 & 31 & 37 & 21 & 48 & 14.0 & - & 一 & - \\
\hline \multirow{2}{*}{$\begin{array}{l}\text { 自 妤 } \\
\text { FTS-11 }\end{array}$} & \multirow{2}{*}{$670 \pm 10^{\circ} \mathrm{C} 1$ 回焼戻し } & 20 & 38 & 67 & 24 & 60 & 24 & 12.3 & 8.7 & 12.0 \\
\hline & & 350 & 40 & 67 & 30 & 58 & 30 & - & 一 & - \\
\hline \multirow{4}{*}{$\begin{array}{l}\text { エレタトロスラグ溶接 } \\
\text { Sv-10NiMo ワイヤ } \\
\text { FTS-7 フタッタス }\end{array}$} & \multirow{2}{*}{$670 \pm 10^{\circ} \mathrm{C}$ 焼 庆 L } & 20 & 40 & 56 & 24 & 67 & 12.8 & - & - & 13.6 \\
\hline & & 370 & 36 & 57 & 21 & 50 & 9.5 & - & - & 12.5 \\
\hline & $950^{\circ} \mathrm{C}$ 广 $5 \mathrm{~L}$ & 20 & 32 & 48 & 18 & 45 & 7.0 & - & - & - \\
\hline & $670 \pm 10^{\circ} \mathrm{C}$ 撓 庆し & 370 & 26 & 48 & - & - & - & - & - & - \\
\hline
\end{tabular}

俑考 FTS-7 フラックスには直径 $8 \mathrm{~mm}$ のワイヤを，FTS-6 と FTS-11 フラックスには值径 $6 \mathrm{~mm}$ のワイヤを用いた值 


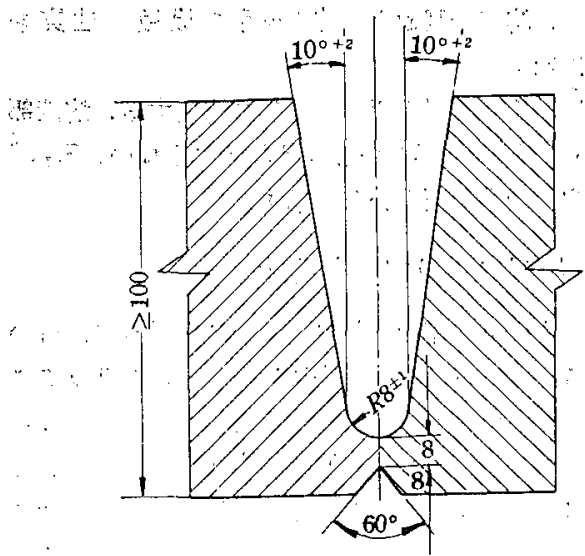

Fig. $10^{\circ}$ 板厚 $100 \mathrm{~mm}$ 以上の $16 \mathrm{MnNiMo}$ 鋼板の多層实合せ継手の開先形状

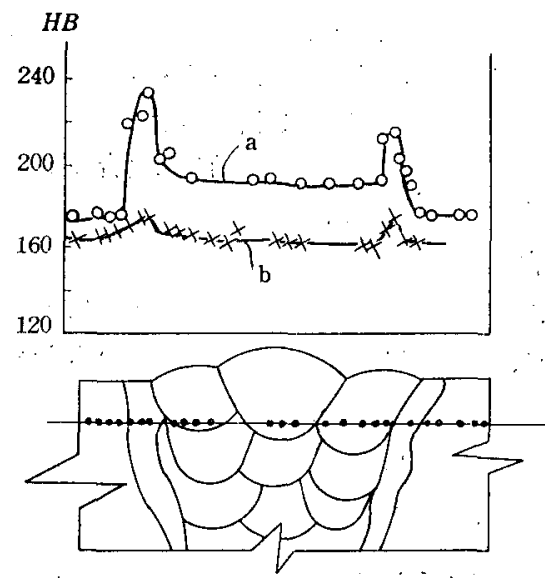

Fig. 11 FTS-7 フラックスを用いた $16 \mathrm{MnNiMo}$ 鋼の溶接継手の硬さ分布 ${ }^{11}$

a) 熱姏理なし $\quad$ b) 二回焼杘し

$670^{\circ} \mathrm{C} \pm 10^{\circ} \mathrm{C}$ の温度で 3 回焼戻しを繰り返せば,"炭 化物の凝集が始まり，硬さで $40 \sim 60$ 低下する， $370^{\circ} \mathrm{C}$ で1000時間時効してもいちじるしい組織の变化は生じな かった。

FTS-7 フラックスは, マンガンー・グネシウムけい 酸塩系 $(24.0 \sim 27.0 \% \mathrm{MnO}, 10 \sim 18 \% \mathrm{MgO})$ に属する。 マンガンおよびけい素反岕に関しては，このフラックス は化学的に活性である ${ }^{18}$ ．乙のため，溶融池内部から分 散した酸化物の介在物を全じ，溶着金属は清浄でない。 最近では，余り活性でない，あるいは完全に反忘がおさ えられたフラックスすいくつか開発されている，てのフ ラックスの一つが, FTS-11 フラックスであり，この FTS-11 フラックスは Sv-10 NiMo ワイヤと組合せれ ば, Table 8 のごとく㡖撃值の高い清浄な多層溶着金属 が得られる。多層溶接後， $670^{\circ} \mathrm{C} \pm 10^{\circ} \mathrm{C}$ で焼戻しをし なければならない.
Table $\theta$ ' $135 \mathrm{~mm}$ 厚の $16 \mathrm{MnNiMo}$ : 鋼 の多層自動溶接条件

\begin{tabular}{|c|c|c|c|c|c|}
\hline \multirow{2}{*}{ 周'数 } & ·溶 & 接 & 44 & \multirow{2}{*}{ 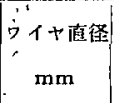 } & \multirow{2}{*}{ 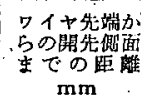 } \\
\hline & $\mid \begin{array}{c}\mathbf{V} \\
\mathbf{T}\end{array}$ & $\begin{array}{c}\mathbf{A} \\
\mathbf{A}\end{array}$ & $\begin{array}{l}\text { 溶接速度 } \\
\mathbf{m} / \mathbf{h r}\end{array}$ & & \\
\hline $1-3$ & $36-38$ & 1000 & 28.0 & 8.0 & 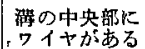 \\
\hline $4-6$ & $34-36$ & 1000 & 30.0 & 8.0 & 8.0 \\
\hline $7-9$ & $36-38$ & 1000 & 25.0 & 8.0 & 9.0 \\
\hline $10-18$ & $36-38$ & 1000 & 25.0 & 8.0 & 9.0 \\
\hline $19-30$ & $36-38$ & $1100^{\circ}$ & 20.0 & 8.0 & 10.0 \\
\hline $31-39$ & $38-40$ & 1200 & 20.0 & 8.0 & 10.0 \\
\hline
\end{tabular}

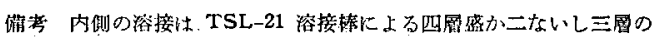
サブマーシ湓接

Table 10 板厚 $135 \mathrm{~mm}$ の $16 \mathrm{MnNiMo}$ 鋼の FTS-7 フラックスによるサブマージ溶接継手を 二度焼戻して， $370^{\circ} \mathrm{C}$ で長時間時効した 後の機械的性望

(平均値)

\begin{tabular}{|c|c|c|c|c|c|c|}
\hline $\begin{array}{c}\text { 時效時閐 } \\
\mathrm{hr}\end{array}$ & $\mid \begin{array}{c}\text { 試跲温度 } \\
{ }^{\circ} \mathrm{C}\end{array}$ & $\begin{array}{l}\text { 降伏 点 } \\
\mathrm{kg} / \mathrm{mm} 2\end{array}$ & \begin{tabular}{|l} 
引張り強ざ \\
$\mathbf{k g} / \mathbf{m m} 2$
\end{tabular} & 伸 $\%$ & $\%^{n}$ & 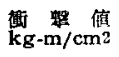 \\
\hline 0 & 20 & 40.5 & 54.5 & 23.2 & 66.4 & 14.5 \\
\hline 100 & 20 & 39.0 & 53.5 & 25.0 & 60.4 & 10.0 \\
\hline 300 & 20 & 40.0 & 53.5 & 25.8 & 56.0 & 11.2 \\
\hline 500 & 20 & 40.5 & 54.3 & 21.8 & 51.2 & 10.2 \\
\hline 700 & 20 & 41.6 & 55.4 & 23.0 & 54.0 & 12.7 \\
\hline 1000 & 20 & 41.8 & 54.8 & 23.1 & 58.0 & 12.0 \\
\hline 0 & 370 & 37.4 & 52.5 & 20.0 & 50.0 & 12.0 \\
\hline 100 & 370 & 36.4 & 52.4 & 22.1 & 54.7 & 9.9 \\
\hline 300 & 370 & 35.4 & 52.4 & 22.4 & 53.8 & 9.4 \\
\hline 500 & 370 & 38.5 & 53.4 & 21.6 & 44.7 & 8.6 \\
\hline $700^{\circ}$ & 370 & 34.8 & 51.2 & 20.0 & 49.5 & 9.2 \\
\hline 1000 & 370 & 33.0 & 49.0 & 24.7 & 59.3 & 10.4 \\
\hline
\end{tabular}

\section{エレクトロスラグ溶接 ${ }^{17}$}

$16 \mathrm{MnNiMo}$ 鎘のエレクトロスラグ溶接は压力容器の シエルの縦溶接に開発された。この溶接材料としては, FTS-7 フラックスと Sv-10NiMo ワイヤの組合せが用 いられる.母材の板厚が $150 \mathrm{~mm}$ 以下の場合には，直 径 $3 \mathrm{~mm}$ ワイヤの一電極エレクトロスラグ溶接を行な う.溶揬継手の焼㞔しおよび烛ならし後烓戻した場合の

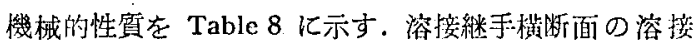
のままの便度分布を Fig. 12 に示す。

溶接直後の溶着金属の顕微鏡組織は，粒界にそったフ ェライトで緣どりされたソルバイト㤠パーライトから成 っている，饬ならしして邺戻されたものでは，細粒フェ ライトーパーライト組織が見られる。

$16 \mathrm{MnNiMo}$ 鋼厚板の性質の均一性を増すために，平 鋼炉をエレクトロスラグ再溶解 (16 MnNiMoS 鋼) し て，普通の平炣鋼と比較した．この両者の䥠の比較を以 下に示す一連の方法によって行なった。 


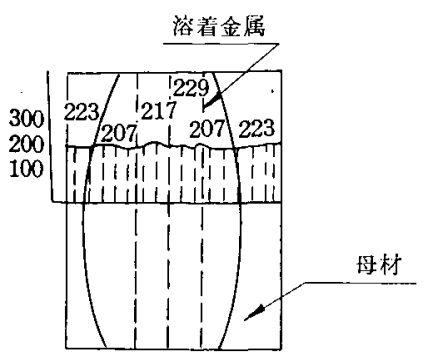

Fig. $1216 \mathrm{MnNiMo}$ 鋼のエレクトロスラグ溶 接継手の硬さ分布(溶接のまま)

\section{サベルカ教授による試験法 ${ }^{18)}$}

この試験法に従って一層サブマージ溶接の瀜合線から の種々の距離でノッチを入れた溶接方向に直角な試片 で, 熱影響部の䘘擊值を求めた。（溶接条件; 溶接電流 $600 \sim 650 \mathrm{~A}$, アーク電压 $35 \sim 38 \mathrm{~V}$, 溶接速度 $40 \mathrm{~m} / \mathrm{hr}$, 板厚 $25 \mathrm{~mm}$ ). 溶接後, 溶接試片は $670^{\circ} \mathrm{C}$ に焼攵され た.との試験結果を Fig. 13 に示す.

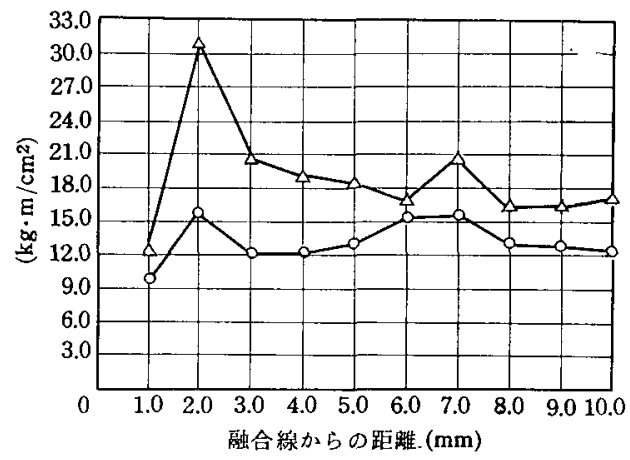

Fig. 13 熱影響部における衝撃值分布 上側の曲線 : $16 \mathrm{MnNiMOS}$ 鋁 下側の曲線 : $16 \mathrm{MnNiMo}$ 銅 (J. Cabelka 法)

\section{融合線上へノッチをつけた試片 の衝撃值}

Fig. 14 に示すように，溶接部ルート部加ら融合線上 へノッチをつけた試片を切り出した。溶接条件は次の通

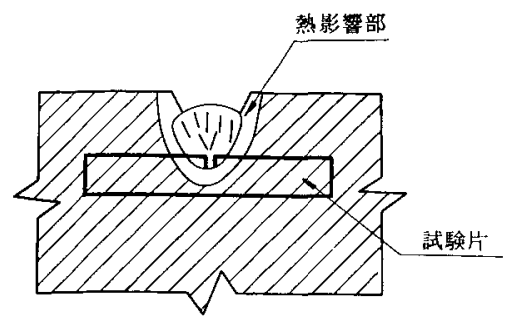

Fig. 14 融合線上に切り欠き頂部を有する ルート溶接の試験片形状

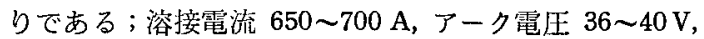
溶接速度 $30 \mathrm{~m} / \mathrm{hr}$. 乙の試験法では実際的な熱影響部全 体としての衙擊破壊に対する抵抗を求め得る。試験結果 を Table 11 に示す.

Table $1116 \mathrm{MnNiMo}$ 鋼および $16 \mathrm{MnNiMoS}$ 鋼 の熱影響部の衝擊值, $\mathrm{kg}-\mathrm{m} / \mathrm{cm}^{2}$

\begin{tabular}{|c|c|c|c|}
\hline \multicolumn{2}{|c|}{$16 \mathrm{MnNiMo}$ 鋼 } & \multicolumn{2}{|c|}{$16 \mathrm{MnNiMoS}$ 鋼 } \\
\hline 溶接のまま & $670 \pm 10^{\circ} \mathrm{C}$ 㱩戻し & 溶接のまま & $670 \pm 10^{\circ} \mathrm{C}$ 㙚扈し \\
\hline 3.5 & 7.7 & 12.7 & 13.0 \\
\hline 5.8 & 10.4 & 11.0 & 11.1 \\
\hline 5.3 & 6.6 & 7.5 & 9.5 \\
\hline 3.2 & 7.5 & 10.8 & 20.5 \\
\hline 4.5 & 8.1 & 11.1 & 13.4 \\
\hline 4.7 & 6.1 & 8.3 & 20.5 \\
\hline$(4.5)$ & $(7.7)$ & $(8.6)$ & $(14.7)$ \\
\hline
\end{tabular}

俑考（）内估平均值を示寸

\section{溶接熱サイクルをうけた試片の 衝撃值}

実際の多層溶接の熱サイクル上同一の溶接熱サイクル を，長方形断面の中央部に TSNIITMASH で設計した $\mathrm{TCW}$ 装置（溶接熱サイクル装置）の設定したプログラ ムにより，融合線加らの距離に対応し再現した。最高加 熱温度は, $700 \sim 1400^{\circ} \mathrm{C}$ である. いくつかの試片は 670 ${ }^{\circ} \mathrm{C} \pm 10^{\circ} \mathrm{C}$ の温度で焼尤しをうける．乙の溶接熱サイク ル再現試片はすべて Mesneges／ッチ試片とした。この 試験結果を Fig. 15 亿示す.

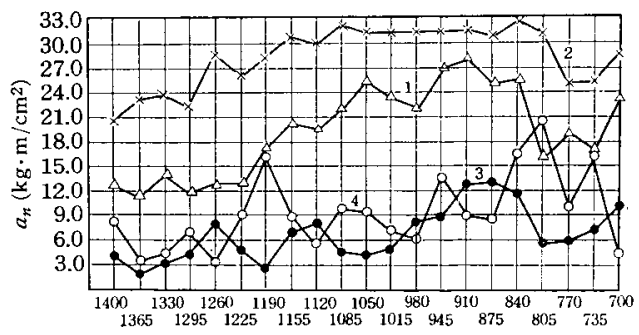

Fig. $1516 \mathrm{MnNiMoS}$ 鋼よよび $16 \mathrm{MnNiMo}$ 鋼 の熱サイクル再現試験片における最高 加熱温度の衝撃值におよぼす影響

1) $16 \mathrm{MnNiMoS}$ 鋼 熱処理なし

2) $16 \mathrm{MnNiMoS}$ 鋼 $670^{\circ} \mathrm{C}$ 焼戻し

3) $16 \mathrm{MnNiMo}$ 鋁 熱処理なし

4) $16 \mathrm{MnNiMo}$ 鋼 $670^{\circ} \mathrm{C}$ 焼帍し

上述のデーターは，他の治金的な好理方法（たとえば 真空溶解）之同じょうに，エレクトロスラグ再溶解が熱 影響部性質の改善の一つの可能な方法であるととを示し ている。

上述の研究により, 大容量ボイラーの溶接ドラムの製 造に対して，ての鋼の使用が可能となったのである， 
この墖交は，著者ら扢よび TSNIITMASH，パトン研 究所，工場の数多くの科学者達や技術者達の研究および 実験結果さらに工業的なデーターをもとに準備したもの である. その中には, G.I. Babushkina, A.I. Rymkevioh, E.G. Malyshevskaya, A.M. Sokolova, V.N. Suslov, B.I. Lazarev, I.E. Tutov, I.L. Brinberg, N.N. Potapov, A.I. Tarnovsky, V.M. Biryukov 他の人々が含まれている. 著者らは，てれら全ての人々に対し特別の謝意を表し ます。

\section{文献}

1) И.Р. Крянин. Металлы для гидротурбин. Изд-во "Машиностроение". Москва, 1969.

2) И.Р. Кряннн, Г.И. Бабушкина. Исследование металлов и технологии для деталей мощиых гидротурбин, сб. ЦНИИТМАШ, №. 46-47, 1964.

3) И.Р. Крянин, Г.И. Бабушкина. Малоуглеродистая нержавеющая сталь ОХ12НдЛ, с6. ЦНИИТмАШ, No. $64-65,1966$.

4) М.Х. Шоршоров. Металловедение сварки стали и силавов титана, Изд-во “Наука", 1965.

5) А.М. Соколова- Исследования технологической прочности сварных соединений гидротурбинных сталей ; автореферат диссертации на соискание ученой стелени кандидата технических наук, ЦНИИТМАШ, 1968.

6) C.L.M. Cottrell, Controlled Thermal Severity Cracking Test Simulates Practical Welding Joints, Welding Journal, No. 6, 1953.

7) А.И. Рымкевич, А.С. Гельман. әлектроплаковая сварка высоколегированных сталея оХ18НЗГЗА $2 Л$ и ОХ12Н дЛ с низколегированной сталью, Сварочное производство, No. 7,1954

8) Г.З. Волошкевич, И.И. Сущук-Слюсаренко, В.П.
Андреев. Изготовление сварно-литых рабочих колес гидротурбин, Автоматическая сварка, №. 2, 1968.

9) Б.E. Патон. Әлектрошлаковая сварка. Москва-Киев, 1959.

10) К.В. Любавский, М.М. Тимофеев. Әлектродная проволока и флюсы для автоматической и полуавтоматической сварки сталей под флюсом. Справочник по сварке, т. 2 под редакцией Е.В. Соколова Машгиз, 1961.

11) К.В. Любавския, Б.И. Лазарев. Сварка высокопрочной стали для толстостенных сосудов высокого давления, сб. под ред. К.В. Любавского, Машгиз, Москва, 1955.

12) К.В. Любавския, Б. И. Лазарев, И.Е. Тутов. Марганцевоникельмолибденовая сталь для барабанов котлов и сосудов высоких и сверхвысоких параметров (сталь 16ГHМ), авторское свидетельство No. 106945 с приоритетом от 11 декабря $1950 \mathrm{r}$.

13) А.П. Гулясв. Металловедение. Москва, 1961.

14) К.В. Любавскии, Б.И. Лазарев. Многопроходная автоматическая сварка котельных сталей больших толщин. Автогенное дело, No. 2, 1949.

15) В.Н. Суслов, В.А. Вдовнн, А.Л. Иванов, В.И. Бирюков, Е.Г. Малышевская. Разработка принципиальнои технологии дуговои өлектросварки рабочего колеса из нержавеющей стали, сб. ЦНИитмАШ, №. 64-65, 1966.

16) В.Н. Суслов, В.А. Вдовип, М.Ф. Хрусталев, Е.Г. Малышевская, В.М. Бирюков, Н.Ф. Терещенко. Әкспериментальные работы по дуговоя әлектросварке стали разных классов и изготовление опытного рабочего колеса гидротурбины Братской ГәС, сб. ЦНИИТМАШ, №. $64-65,1966$.

17) И.Л. Бринберг, Л.В. Голуб. Әлектрошлаковая сварка стали 16ГНМ, Сварочное пронзводство, №. 9, 1955.

18) J. Cabelka. Svaritelnost makkych konstrucnych oceli, Bratislava, 1918.

19) К.В. Любавскии. Металлургия сварки сталей плавлением. Справочник по сварке, Машгиз, 1961 г.

(益本 功, 策田 剛訳)

\section{イオン理論からみたエレクトロ・スラグ溶解法 における冶金反応*}

J. ゼ

\section{Metallurgical Processes During Electroslag Melting Process from}

The Viewpoint of Ion Theory*

by Július Zeke**

\section{1. 緒}

エレクトロ・スラグ溶解法はキエフのパトン溶接研究 所で創始された方法であって，乙れに使う材料はサブマ ージ・アーク溶接法の知識をもとにしていた。技術開発 の初期のころは，エレクトロ・スラグ溶接のフラックス

* 原稿受付 腃和 45 年 1 月 8 日

** ブラチスラバ容接研究所 Welding Research Institute,

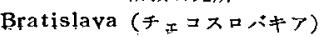

としてサブマージ・アーク溶接のものと同じものを使用 していた。 そして溶接の場合だけでなく，溶解の場合る 同棣であった。

スラグと溶瀜金属浴の間で尔きる治金反応過程の説明 あ，実際にはサブマージ・アーク溶接と同様に，エレク トロ・スラグ溶接およびエレクトロ・スラグ溶解の場合 を考えてきたのであるが，その説明の多くはスラグ構造 を分子論的に扱ったものであった。 